\title{
Structure-based virtual screening of bioherbicide candidates for weeds in sugarcane plantation using in silico approaches
}

\author{
Penapisan virtual berdasarkan struktur kandidat bioherbisida untuk gulma pada perkebunan tebu \\ menggunakan pendekatan in silico
}

Galuh Wening PERMATASARI*), Riza Arief PUTRANTO, \& Happy WIDIASTUTI

Indonesian Research Institute for Biotechnology and Bioindustry, Jl. Taman Kencana No 1, Bogor 16128

Diterima tgl 23 Mei 2020 / disetujui tgl 9 Oktober 2020

\begin{abstract}
Abstrak
Gulma pada perkebunan tebu berdampak negatif pada produktivitas tebu. Beberapa pendekatan telah dilakukan untuk menangani gulma, termasuk penggunaan diuron sebagai herbisida sintetik. Bagaimanapun, penggunaan diuron dalam jangka panjang berefek buruk dan menyebabkan produksi 3,4-Dichloroaniline yang akumulasinya dapat menyebabkan pengikisan hara tanah. Oleh sebab itu, penelitian ini bertujuan untuk mencari herbisida alami. Dengan meniru mekanisme diuron yang menghambat proses fotosintesis pada protein fotosistem II DI (psbA) yang terdapat pada gulma, empat belas senyawa sebagai kandidat potensial bioherbisida ditambatkan secara virtual menggunakan program PyRx v.0.9.5 pada situs yang spesifik. Tiga spesies gulma utama yang dipilih adalah Eleusine indica, Praxelis clematidea, dan Momordica charantia. Skor ikatan afinitas selanjutnya dikalkulasi dan diperingkat untuk penapisan enam senyawa terbaik sebagai kandidat bioherbisida. Interaksi setiap kompleks dan prediksi aktivitas biologis kemudian dilakukan dengan program Discovery Studio dan PASS server, secara berurutan. Aurachin $P$, Aurachin A, dan Cyanobacterin muncul pada peringkat teratas dengan skor afinitas yang tinggi pada psbA yakni -6 hingga -9 $\mathrm{kkal} \mathrm{mol}^{-1}$. Interaksi asam amino yang terlibat pada kompleks menunjukkan 50-90\% kesamaan pada kompleks kontrol, yakni psbA dan diuron. Di samping itu, prediksi aktivitas biologis Aurachin P, Aurachin A, dan Cyanobacterin menunjukkan istilah yang terkait dengan inhibisi proses fotosintesis melalui jalur enzimatis. Maka, senyawa aktif tersebut kemungkinan memiliki aksi penghambatan proses fotosintesis dan mengendalikan gulma pada perkebunan tebu.
\end{abstract}

[Kata kunci: diuron, penambatan molekul, penghambatan fotosintesis]

\footnotetext{
Abstract

Weeds in sugarcane have negatively affected the sugar yield rate. Several approaches have been carried out to overcome the weeds, including the usage of diuron as synthetic herbicide. However,
}

the long-term usage of diuron is known to have a negative effect leads to the production of 3,4Dichloroaniline responsible for soil leach and bioaccumulation. Therefore, this study aimed to find a potential natural herbicide. By mimicking the diuron's mode of action which inhibits the process of photosynthesis through blocking the Photosystem II protein D1 (psbA) of the weeds, fourteen compounds as potential candidate bioherbicides were virtually docked by PyRx v.0.9.5 software to the specific site. Three important species of the weeds were chosen including Eleusine indica, Praxelis clematidea, and Momordica charantia. The binding affinity score was further calculated and ranked to screen the top six compounds as bioherbicide candidates. Interaction of each complex and the biological activity prediction were then performed by Discovery Studio software and PASS server, respectively. Aurachin P, Aurachin A, and Cyanobacterin were placed in the top ranked compounds with high binding affinity score around -6 to $-9 \mathrm{kcal} \mathrm{mol}^{-1}$ toward the psbA. The amino acid interaction involved in the complex shows 50-90\% similar to the control, psbA and diuron complex. Besides, the biological activity prediction of Aurachin P, Aurachin A, and Cyanobacterin exhibits the terms related to the inhibition of photosynthesis process via enzymatic pathway. Thus, the active compounds might have inhibition action in the photosynthesis process and control the weeds in sugarcane.

[Keywords: diuron, molecular docking, photosynthesis inhibition]

\section{Introduction}

Controlling weeds in sugarcane is a challenge that farmers should face. The growth of weeds itself is faster than the sugarcane (Saccharum officinalis L.), mainly in the early stages of crop growth. Yields of sugarcane reported decrease around 24 to $93 \%$ as a result of nutrient loss by competing with crops for water, nutrients, and sunlight (Singh \& Kumar, 2013). Singh et al. (2011) highlighted a significant increase of the sugarcane weeds in the plantation as farmers have 
limited expertise and knowledge to improve the weed management.

The utilization of herbicides is a common practice in weed management of plant crops. Previous research reported the high efficacy of herbicides (90-99\%) in killing weeds (Wakabayashi \& Boger, 2002; Délye et al., 2013). In the USA, herbicides have been widely used $(95 \%)$ in cotton, soybean, maize, and sugar beet (Gianessi, 2005). Based on the Sistem Informasi Pestisida database in 2020, the usage of herbicides in Indonesia is targeted to many commodities including acacia, orchid, grapes, apple, corn mill, onion, and shallot. However, chemical herbicides usage has been banned due to the negative effects in soil health, aquatic environments, and the atmosphere. The substance also has negative effects to human health and ecosystem sustainability (Morales et al., 2013; Huovinen et al., 2015; Velki et al., 2019).

Diuron is one of the most familiar synthetic herbicides used by farmers to control weeds in their sugar plantation (Peng, 2012). The substance belongs to the phenyl amide family and acts as a photosynthesis inhibitor by preventing oxygen production (Wessels \& Veen, 1956). In addition, it blocks the electron transfer in the photosystem II (PSII). The D1 protein is the center of the PSII reaction and $\mathrm{C}$-terminal processing of the precursor D1 protein is important (Teixeira \& Elzbieta, 2013). Some reports mentioned the substance effectivity in killing the annual and perennial grassy weeds. It has been widely used in plant crops such as cotton, sugarcane, alfalfa, and wheat. However, the usage of diuron has been reported to cause environmental problems. Diuron has been detected in $28 \%$ of river samples in the USA National Canal System. Besides, the presence of diuron produces the intermediate substances, leading to the formation of 3,4-Dichloroaniline (3,4-DCA) which causes soil leaching and bioaccumulation (Giacomazzi \& Cochet, 2004). While in Indonesia, the diuron usage mainly for sugarcane is still allowed. The regulation in Indonesia allowing the diuron used as an active compound for ten brands of pesticides, including Amrocon 80 WP, Bioron 80 WP, Gonzales 80 WP, Gulmaron 500 SC, Gulmaron 80 WP, Maron 80 WP, Ronindo 500 SC, Ronindo 80 WP, Sidaron 80 WP, and Viaron 500 SC (Sistem Informasi Pestisida, 2020). If this condition continues to happen, it might affect soil health in the environment. This finding leads to the classification of diuron as a harmful substance causing the suppression of its utilization within 20 years based on the Directive 2000/60/CE. To overcome this condition, researchers tried to develop herbicides derived from the secondary metabolite of plant species and microbes to minimize the environmental effects and creating safer and non-toxic compounds (Nusrat et al., 2018; Radhakrishnan et al., 2018). Dayan \& Duke
(2014) have reviewed the varieties of nextgeneration herbicides from natural compounds and the detailed mechanisms of action. This article was used as a database of bioherbicides source in this study. This study provides insight into finding the bioherbicides virtually using the structural bioinformatics approach that incorporates a molecular docking method to find better performance and safer bioherbicides than diuron. The analysis was based on its mechanism of action to block the photosynthesis process in sugarcane. Targeting the protein and predicting the binding affinity using the molecular docking approach have been used years for the drug discovery process (Meng et al., 2011; Pinzi \& Rastelli, 2019) due to its accuracy and effectivity to screen the candidates. The approaches were then adopted to find the candidates of bioherbicides targeting a specific protein in plants.

\section{Material and Methods}

\section{Samples retrieval of bioherbicide candidates}

The candidate of the bioherbicides list was retrieved from the review paper of Dayan \& Duke (2014). This previous study provided the list of the mechanism of action (MOA) which is targeting PSII electron transport and its sources for bioherbicides. The compounds classified as natural phytotoxin isolates from various organisms (Sorghum bicolor, Syctonema hofmanni, Fischerella muscicola, and Stigmatella aurantica). The 3D structure of the candidate compounds was obtained from the PubChem database (https://pubchem.ncbi.nlm.nih.gov) with the unique ID (Table 1).

Protein sequences retrieval, modeling, and $3 D$ structure analysis

Three types of weeds: Eleusine indica, Praxelis clematidea, and Momordica charantia were chosen based on the field observation. The sequences of Photosystem II protein D1 (psbA) from E. indica (ID K9MXP5), $P$. clematidea (ID W8RMZ2), and M. Charantia (ID A0A2I6BZY2) were retrieved from the Uniprot database (https://uniprot.org). The protein target was further modeled utilizing I-TASSER software (https://zhanglab.ccmb. medumich.edu/ITASSER/) (Yang \& Zhang, 2015) with a unique template having high similarity with the structure of amino acid sequences. The considerations were made to choose the proper model protein from ITASSER including (1) The rank of proteins, which is based on TM-score of the structural alignment between the query structure and known structures in the PDB library; (2) The lowest Root Mean Square Deviation (RMSD ${ }^{\mathrm{a}}$ ) score, represents the smallest RMSD value between residues that are structurally aligned by TM-align; (3) The highest IDEN $^{\mathrm{a}}$, represents the highest percentage sequence identity in the structurally aligned 
Menara Perkebunan 2020, 88(2), 100-110

Table 1. Candidates for natural compounds of bioherbicides from PubChem database Tabel 1. Kandidat bioherbisida asal senyawa alami dari database PubChem

\begin{tabular}{|c|c|c|c|c|}
\hline $\begin{array}{c}\mathrm{CID} \\
\text { Nomor identitas }\end{array}$ & $\begin{array}{l}\text { Chemical formula } \\
\text { Rumus kimia }\end{array}$ & $\begin{array}{l}\text { Chemical structure } \\
\text { Struktur kimia }\end{array}$ & $\begin{array}{l}\text { Molecular weight } \\
\left(\mathrm{g} \mathrm{mol}^{-1}\right) \\
\text { Berat molekul } \\
\left(\mathrm{g} \mathrm{mol}^{-1}\right)\end{array}$ & $\begin{array}{l}\text { Compound name } \\
\text { Nama senyawa }\end{array}$ \\
\hline 3120 & $\mathrm{C}_{9} \mathrm{H}_{10} \mathrm{Cl}_{2} \mathrm{~N}_{2} \mathrm{O}$ & & 233.09 & $\begin{array}{l}\text { Diuron } \\
\text { (control) }\end{array}$ \\
\hline 25157870 & $\mathrm{C}_{25} \mathrm{H}_{33} \mathrm{NO}_{4}$ & & 411.5 & Aurachin P \\
\hline 122706081 & $\mathrm{C}_{25} \mathrm{H}_{33} \mathrm{NO}_{3}$ & & 395.5 & $\begin{array}{l}\text { Aurachin B } \\
\text { epoxide }\end{array}$ \\
\hline 25188767 & $\mathrm{C}_{25} \mathrm{H}_{33} \mathrm{NO}_{3}$ & & 395.5 & Aurachin $\operatorname{Re}$ \\
\hline 6439172 & $\mathrm{C}_{25} \mathrm{H}_{33} \mathrm{NO}_{3}$ & & 395.5 & Aurachin A \\
\hline 6439171 & $\mathrm{C}_{25} \mathrm{H}_{33} \mathrm{NO}_{2}$ & & 379.5 & Aurachin C \\
\hline 6124753 & $\mathrm{C}_{25} \mathrm{H}_{33} \mathrm{NO}$ & & 363.5 & Aurachin D \\
\hline 13746957 & $\mathrm{C}_{26} \mathrm{H}_{32} \mathrm{~N}_{2} \mathrm{O}_{2}$ & & 404.5 & Aurachin E \\
\hline 6439168 & $\mathrm{C}_{25} \mathrm{H}_{33} \mathrm{NO}_{2}$ & & 379.5 & Aurachin B \\
\hline 90657799 & $\mathrm{C}_{25} \mathrm{H}_{33} \mathrm{NO}_{3}$ & & 395.5 & $\begin{array}{l}\text { Aurachin-C } \\
\text { epoxide }\end{array}$ \\
\hline
\end{tabular}


Table 1. (continue)

\begin{tabular}{|c|c|c|c|c|}
\hline $\begin{array}{c}\text { CID } \\
\text { Nomor identitas }\end{array}$ & $\begin{array}{l}\text { Chemical formula } \\
\text { Rumus kimia }\end{array}$ & $\begin{array}{c}\text { Chemical structure } \\
\text { Struktur kimia }\end{array}$ & $\begin{array}{l}\text { Molecular weight } \\
\left(\mathrm{g} \mathrm{mol}^{-1}\right) \\
\text { Berat molekul } \\
\left(\mathrm{g} \mathrm{mol}^{-1}\right)\end{array}$ & $\begin{array}{l}\text { Compound name } \\
\text { Nama senyawa }\end{array}$ \\
\hline 5353970 & $\mathrm{C}_{30} \mathrm{H}_{42} \mathrm{O}_{7}$ & & 514.6 & Stigmatellin \\
\hline 6437843 & $\mathrm{C}_{23} \mathrm{H}_{23} \mathrm{ClO}_{6}$ & & 430.9 & Cyanobacterin \\
\hline 70684692 & $\mathrm{C}_{20} \mathrm{H}_{29} \mathrm{NO}$ & & 299.4 & Fischerellin B \\
\hline 14427830 & $\mathrm{C}_{22} \mathrm{H}_{30} \mathrm{O}_{4}$ & & 358.5 & Sorgoleone 358 \\
\hline 135476235 & $\mathrm{C}_{26} \mathrm{H}_{36} \mathrm{~N}_{2} \mathrm{O}_{2}$ & & 408.6 & Fischerellin A \\
\hline
\end{tabular}

region; and (4) The highest value of Cov score represents the highest coverage of the alignment by TM-align and is equal to the number of structurally aligned residues divided by the length of the query protein. To compare the psbA structure between three weeds, the amino acid sequences were aligned using MUSCLE in BioEdit software (Hall, 2011). The RMSD of each 3D structure protein was calculated to reveal the structure differences using PyMol (Schrödinger, USA) (The PyMOL Molecular Graphics System, Version 1.2r3pre, Schrödinger, LLC).

\section{Molecular docking analysis and visualization}

In order to understand the molecular interaction and affinity binding between bioherbicide candidate compounds and psbA, virtual screening in molecular docking was carried out using PyRx 0.9.5 software developed by Dallakyan \& Olson (2015) and has been widely used (de Sousa et al., 2020; Kulkarni et al., 2020; Venkateshan et al., 2020). The research design simply looked for the inhibitor of the psbA and found a better natural compound candidate than diuron. The grid used for docking analysis was center X: 65368, Y: 81888, Z: 91545, dimensions ( $)$ X: 7168, Y: 7358, and $\mathrm{Z}$ : 10405 . The docking was done specifically at diuron's binding site as a control. The docking complex and amino acid interaction were visualized using Discovery Studio R2017 (Dassault Systèmes BIOVIA, BIOVIA Visualizer, Release 2017).

\section{Biological activity prediction}

In order to explore the biological activity of candidate compounds, prediction analysis was carried out using the PASS server website (http://www.pharmaexpert.ru/passonline/index.ph p). This web server calculated the biological activity based on the structural similarity in the database. It scored the prediction range from 0 to 1. The score above 0.7 represents the prediction accuracy of the laboratory test (Filimonov et al., 2018).

\section{Results and Discussion}

Amino acid sequence alignment, protein modeling, and RMSD analysis

Amino acids sequences were aligned using MUSCLE to identify the possibility of structure variation of psbA among three weeds. The alignment showed the amino acid differences among 353 amino acids between psbA in three weeds of E. indica, P.Clematidea, and 
M. charantia (Figure 1). Three amino acids differences appeared in the psbA of $P$. Clematidea including residue pairs number $11(\mathrm{~T} \rightarrow \mathrm{E}) ; 346$ $(\mathrm{L} \rightarrow \mathrm{I})$; and $351(\mathrm{~L} \rightarrow \mathrm{T})$. While in M. charantia, six differences were found in residue pairs 11 $(\mathrm{T} \rightarrow \mathrm{E}) ; 238(\mathrm{~K} \rightarrow \mathrm{R}) ; 346(\mathrm{~L} \rightarrow \mathrm{V}) ; 348$ $(\mathrm{A} \rightarrow \mathrm{V}) ; 349(\mathrm{P} \rightarrow \mathrm{T})$; and $351(\mathrm{~L} \rightarrow \mathrm{I})$ compared to the E. indica protein sequences.

The protein structure was modelled to visualize the 3D structure of psbA from those three weeds. The template 4YUUA was selected by the ITASSER algorithm among thousands of proteins in LOMET database (Figure 2A-C). The superimpose analysis was carried out by calculating the RMSD scores representing the atomic distances to identify the structure differences (Figure 2D). The psbA of $E$. indica and $P$. clematidea has RMSD score of 1.016, whilst the $E$. indica and $M$. charantia; $M$. charantia and $P$. clematidea showed approximately similar RMSD scores, around 0.9 (Table 2). The data confirmed that structure variation among those three proteins was found.

The distance-based measurement by RMSD analysis of each D1 protein from $E$. indica, $P$. clematidea and $M$. charantia exhibited deviation score, $\sim 1 \AA$ A. A report from Eyal et al. (2005) stated the limit of accuracy of protein modeling is $\sim 8 \AA$, which leads to the conclusion that the D1 protein has no meaningful differences in terms of structure and function. The RMSD value was calculated based in the pairs of atoms and the distance between two atoms (Kufareva \& Abagyan, 2012). Slight differences were spotted in the 3D structure of D1 protein from each weed species when visualized using superimpose approaches, which supports the RMSD values (Figure 2D, red circle).

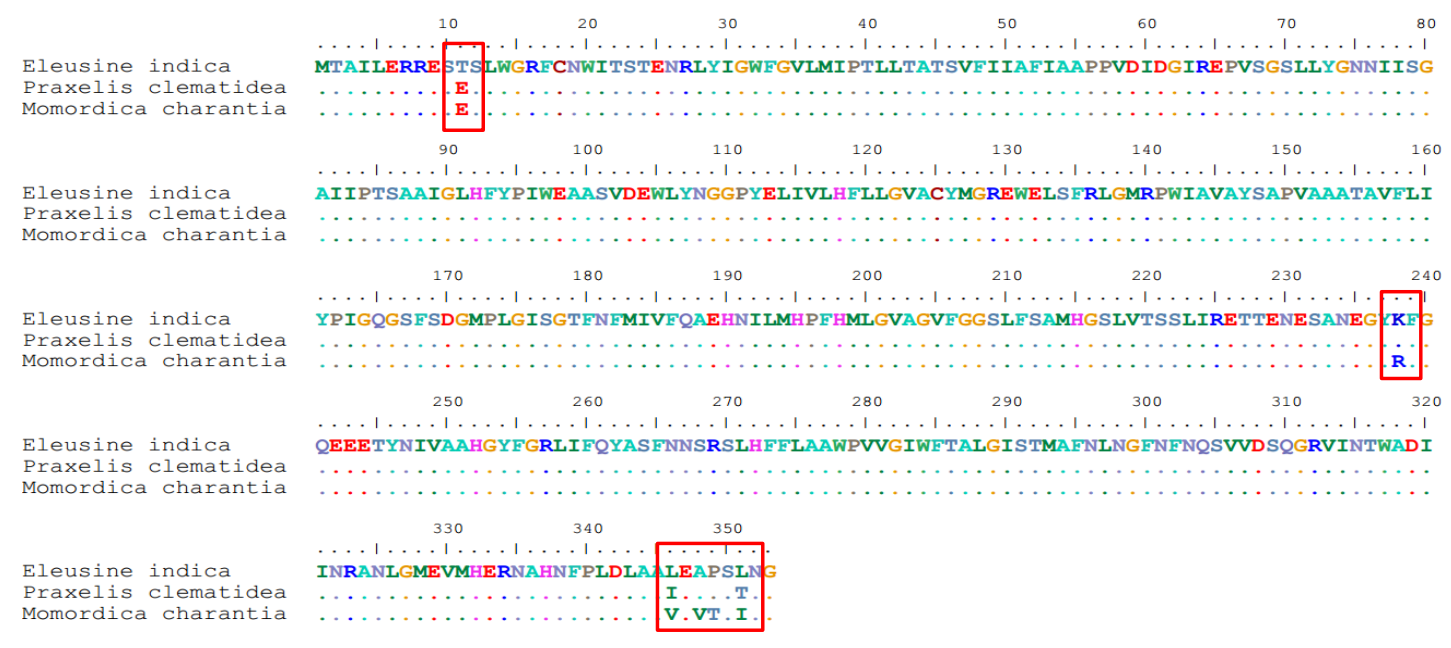

Figure 1. Protein sequence alignment of psbA in E. indica, $P$. clematidea and $M$. charantia. The amino acids sequences were aligned using MUSCLE with parameters BLOSUM98 matrix. The red box shows differences of amino acid sequences from three psbA

Gambar 1. Pensejajaran sekuen psbA dari spesies E. indica, P. clematidea dan M. charantia. Pensejajaran dilakukan menggunakan MUSCLE dengan parameter matriks BLOSUM98. Kotak merah menunjukkan perbedaan sekuen asam amino dari tiga psbA
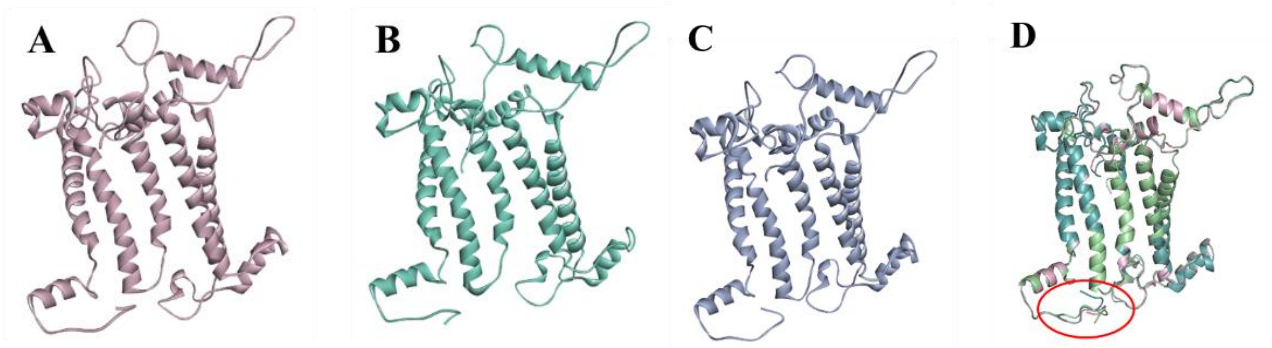

Figure 2. Protein modelling of psbA A) E. indica, B) P. clematidea, C) M. charantia, D) Superimposed visualization of three compared proteins. The superimpose was visualized in PyMOL to calculate the RMSD values for each comparison. Red circle shows the gap differences among models

Gambar 2. Pemodelan protein D1 Photosystem II dari A) E. indica, B) P. clematidea, C) M. charantia, D) visualisasi dari superimpose tiga protein D1 photosystem II dari masing-masing spesies gulma menggunakan PyMOL untuk kalkulasi nilai RMSD. Lingkaran merah menunjukkan perbedaan rentang nilai RMSD antar model 
Virtual screening of molecular docking analysis of bioherbicide compound candidates

The molecular interaction of each psbA from each weed was observed to the compound candidates. Fourteen candidates of bioherbicide were selected based on Dayan \& Duke (2014) and docked into the psbA, compared to the diuron as the control. The virtual screening approach could examine a target and a subset of compounds in order to reduce the number of compounds to test in the laboratory. It predicts ligand binding modes by specific algorithms in computational technique. The scoring results represent the global minimum of the energy needed for the interaction (Salmaso \& Moro, 2018).
The top six compounds were ranked from each complex based on the binding affinity score. Aurachin P, Aurachin A, and Cyanobacterin appeared in the top six of each protein complexes from different psbA weeds species. Cyanobacterin showed the highest potential as a candidate compound to block D1 protein of $E$. indica, followed by Aurachin $\mathrm{P}$ and Aurachin A, with affinity score $-6.7,-6.2$, and $-6.2 \mathrm{kcal} \mathrm{mol}^{-1}$, respectively. While in complex with psbA of $P$. clematidea, Aurachin A exhibited high affinity, followed by Aurachin $\mathrm{P}$ and Cyanobacterin. Aurachin $\mathrm{P}$ was first among other compounds in the interaction with psbA of $M$. charantia, followed by Aurachin A and Cyanobacterin (Table 3). Those three compounds exhibited a higher binding affinity than the diuron as control.

Table 2. RMSD analysis of psbA of E. indica, $M$. charantia, and P. clematidea

Tabel 2. Analisis RMSD psbA dari spesies E. indica, M. charantia, dan P. clematidea

\begin{tabular}{llc}
\hline Species 1 & Species 2 & RMSD value $(\AA)$ \\
Spesies 1 & Spesies 2 & Nilai RMSD $(\AA)$ \\
\hline E. indica & M. charantia & 0.912 \\
E. indica & P. clematidea & 1.016 \\
M. charantia & P. clematidea & 0.931 \\
\hline
\end{tabular}

Table 3. Binding affinity score of psbA and candidate compounds of bioherbicide. Virtual screening in molecular docking was carried out using PyRx 0.9.5. Yellow highlight shows the top 6 score of docking

Tabel 3. Skor afinitas ikatan dari psbA dan kandidat bioherbisida. Skrining virtual dilakukan dengan penambatan molekular menggunakan software PyRx 0.9.5. Tanda kuning menunjukkan 6 skor penambatan teratas

\begin{tabular}{|c|c|c|c|c|c|c|c|c|}
\hline $\begin{array}{l}\text { Receptor } \\
\text { Reseptor }\end{array}$ & $\begin{array}{l}\text { Ligand } \\
\text { Ligan }\end{array}$ & $\begin{array}{c}\text { Binding } \\
\text { Affinity } \\
(\mathrm{kcal} / \mathrm{mol}) \\
\text { Afinitas ikatan } \\
(\text { kkal/mol })\end{array}$ & $\begin{array}{l}\text { Receptor } \\
\text { Reseptor }\end{array}$ & $\begin{array}{l}\text { Ligand } \\
\text { Ligan }\end{array}$ & $\begin{array}{c}\text { Binding } \\
\text { Affinity } \\
(\mathrm{kcal} / \mathrm{mol}) \\
\text { Afinitas ikatan } \\
(\text { kkal/mol })\end{array}$ & $\begin{array}{l}\text { Receptor } \\
\text { Reseptor }\end{array}$ & $\begin{array}{l}\text { Ligand } \\
\text { Ligan }\end{array}$ & $\begin{array}{c}\text { Binding } \\
\text { Affinity } \\
\text { (kcal/mol) } \\
\text { Afinitas } \\
\text { ikatan } \\
\text { (kkal/mol) }\end{array}$ \\
\hline \multirow{15}{*}{$\begin{array}{l}\text { Eleusine } \\
\text { indica }\end{array}$} & $\begin{array}{l}\text { Diuron } \\
\text { (control) }\end{array}$ & -5.4 & \multirow{15}{*}{$\begin{array}{c}\text { Praxelis } \\
\text { clematidea }\end{array}$} & $\begin{array}{l}\text { Diuron } \\
\text { (control) }\end{array}$ & -6 & \multirow{15}{*}{$\begin{array}{c}\text { Momordica } \\
\text { charantia }\end{array}$} & $\begin{array}{l}\text { Diuron } \\
\text { (control) }\end{array}$ & -6.3 \\
\hline & Cyanobacterin & -6.7 & & $\begin{array}{l}\text { Aurachin B } \\
\text { epoxide }\end{array}$ & -7.6 & & Aurachin P & -9 \\
\hline & Aurachin E & -6.4 & & Aurachin Re & -7.5 & & Aurachin A & -8.9 \\
\hline & Aurachin B & -6.3 & & Aurachin A & -7.5 & & Aurachin D & -8 \\
\hline & Aurachin P & -6.2 & & Aurachin $\mathrm{P}$ & -7.4 & & $\begin{array}{l}\text { Aurachin-C } \\
\text { epoxide }\end{array}$ & -8 \\
\hline & Aurachin A & -6.2 & & Aurachin E & -7.2 & & $\begin{array}{l}\text { Aurachin B } \\
\text { epoxide }\end{array}$ & -7.9 \\
\hline & Aurachin D & -6.1 & & Cyanobacterin & -6.8 & & Cyanobacterin & -7.9 \\
\hline & $\begin{array}{l}\text { Aurachin B } \\
\text { epoxide }\end{array}$ & -6 & & Aurachin B & -6.8 & & Aurachin B & -7.9 \\
\hline & Aurachin C & -6 & & $\begin{array}{l}\text { Aurachin-C } \\
\text { epoxide }\end{array}$ & -6.8 & & Aurachin E & -7.8 \\
\hline & $\begin{array}{l}\text { Aurachin-C } \\
\text { epoxide }\end{array}$ & -5.8 & & Aurachin D & -6.6 & & Aurachin C & -7.8 \\
\hline & Aurachin Re & -5.7 & & Sorgoleone 358 & -6.5 & & \multirow{2}{*}{$\begin{array}{l}\text { Aurachin Re } \\
\text { Sorgoleone } \\
358\end{array}$} & -7.7 \\
\hline & Sorgoleone 358 & -5.3 & & Aurachin C & -6.5 & & & -6.5 \\
\hline & Stigmatellin & -4.9 & & Fischerellin B & -6.2 & & Fischerellin B & -6.3 \\
\hline & Fischerellin B & -4.8 & & Stigmatellin & -5.7 & & Stigmatellin & -5.7 \\
\hline & Fischerellin A & -0.9 & & Fischerellin A & -0.9 & & Fischerellin A & -0.8 \\
\hline
\end{tabular}


The complex interaction was analysed to find out the type of the involved amino acid (Figure 3). Mostly, the complex shows van der Waals interaction between molecules (Table 4, green bubble). The analysis showed $50 \%-90 \%$ of amino acids responsible in the interaction between Aurachin A, Aurachin P, and Cyanobacterin were similar to the complex psbA and diuron for each weed species (Table 4). The high similarity of the binding site represents the resemblance of function candidate compounds as D1 protein blocker. Some of them bind into specific amino acids which has an important function. Based on the UniProt database, the amino acid involved in the interaction has several important roles. Amino acid (AA) number 161 has a function in tyrosine radical intermediate, AA number 170 and 333 playing role in the calcium-manganese-oxide [Ca-4Mn-5O]; manganese 1 and 4.
Biological potential activity of Aurachin $P$, Aurachin $P$ and Cyanobacterin

In order to explore the potential of Aurachin P, Aurachin A, and Cyanobacterin, biological activity prediction was conducted (Table 5). The data explaining the potential activity of Aurachin P and Aurachin A was similar, mostly related to the inhibitory activity of prenyl-diphosphatase, undecaprenyl-phosphate mannosyl transferase, and plastoquinol-plastocyanin reductase inhibitor. Those terms related to the inhibition of enzyme and catalytic activity playing an important role in photosynthesis. In contrast, Cyanobacterin acts as a 1-Acylglycerol-3-phosphate O-acyltransferase inhibitor, related to the negative regulation of phosphatic acid biosynthesis. The activity of candidate bioherbicides supports the prediction to inhibit the photosynthesis process in weeds.
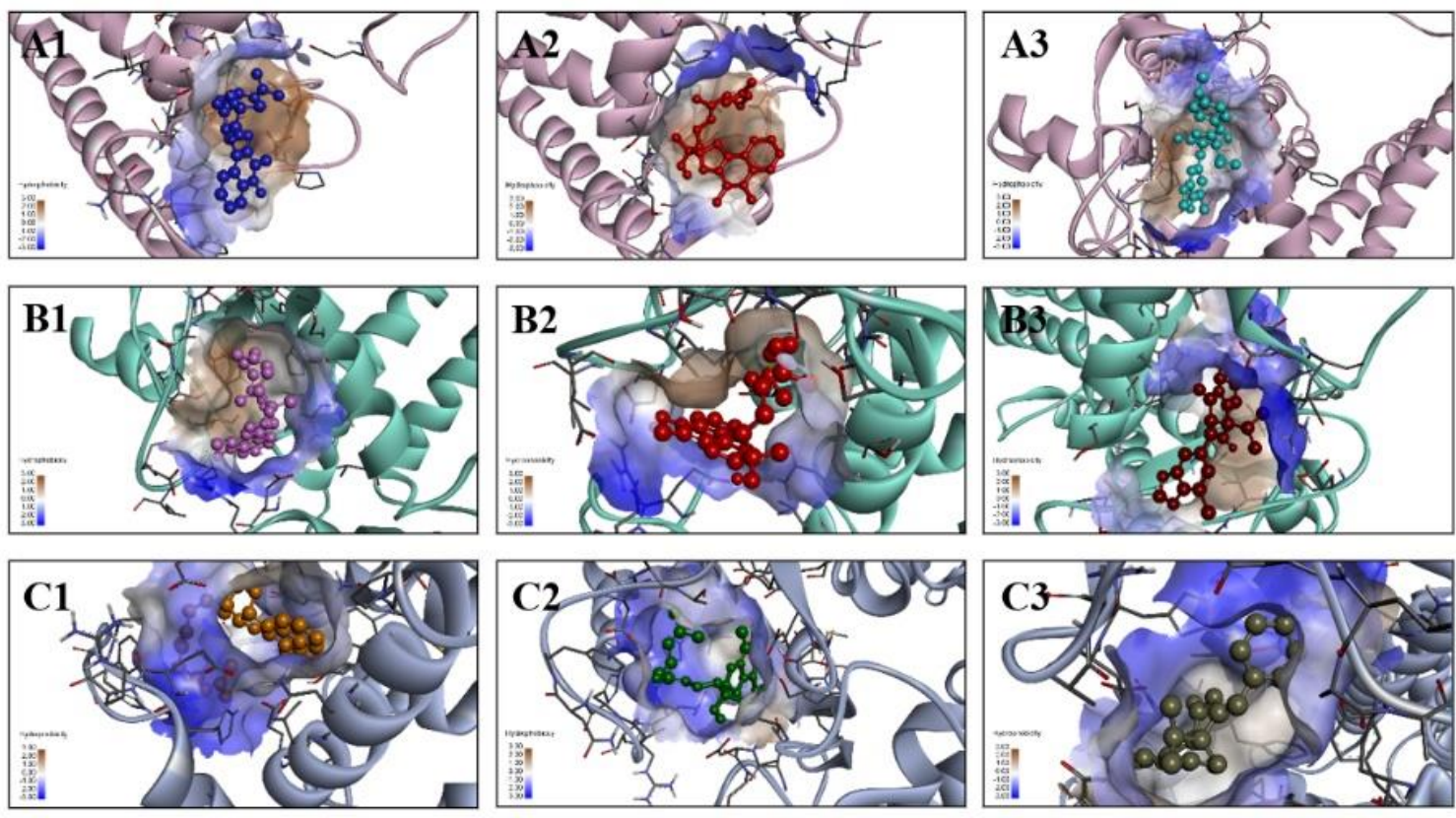

Figure 3. Molecular docking interaction between psbA (cartoon) and bioherbicide candidates (ball and sticks): (A1) D1 protein of E. indica and Aurachin P, (A2) D1 protein of E. indica and Aurachin A, (A3) D1 protein of E. indica and Cyanobacterin; (B1) D1 protein of P. clematidea and Aurachin P, (B2) D1 protein of P. clematidea and Aurachin A, (B3) D1 protein of P. clematidea and Cyanobacterin; (C1) D1 protein of M. charantia and Aurachin P, (C2) D1 protein of $M$. charantia and Aurachin A, (C3) D1 protein of $M$. charantia and Cyanobacterin. The docking complexes were visualized using Discovery Studio R2017

Gambar 3. Interaksi molekular docking antara psbA (kartun) dan kandidat bioherbisida (garis dan bola): (A1) Protein psbA E. indica dan Aurachin P, (A2) Protein psbA E. indica dan Aurachin A, (A3) Protein psbA E. indica dan Cyanobacterin; (B1) Protein psbA P. clematidea dan Aurachin P, (B2) Protein psbA P. clematidea dan Aurachin A, (B3) Protein psbA P. clematidea dan Cyanobacterin; (C1) Protein psbA M. charantia dan Aurachin P, (C2) Protein psbA M. charantia dan Aurachin A, (C3) Protein psbA M. charantia dan Cyanobacterin. Kompleks hasil penambatan divisualisasikan menggunakan Discovery Studio R2017 
Table 4. Amino acid interaction between psbA of each weed species and potential candidate bioherbicides Aurachin P, Aurachin A, and Cyanobacterin. The bold font emphasizes the amino acid that also found in the diuron (control)

Tabel 4. Interaksi asam amino antara kompleks psbA dari masing-masing spesies gulma dan kandidat bioherbisida Aurachin P, Aurachin A, dan Cyanobacterin. Huruf tebal menunjukkan asam amino yang ditemukan juga pada diuron (kontrol)

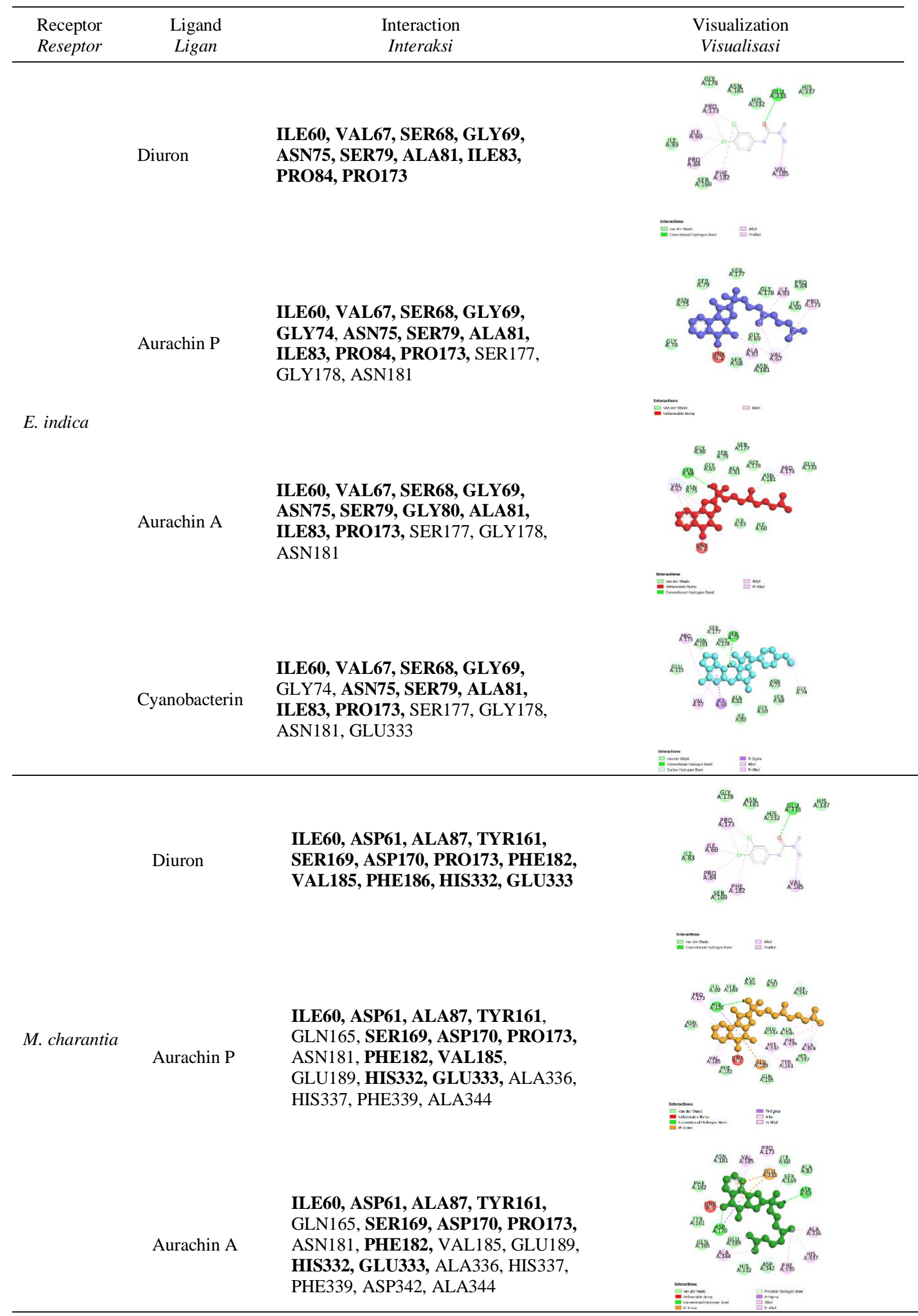


Table 4. (continue)

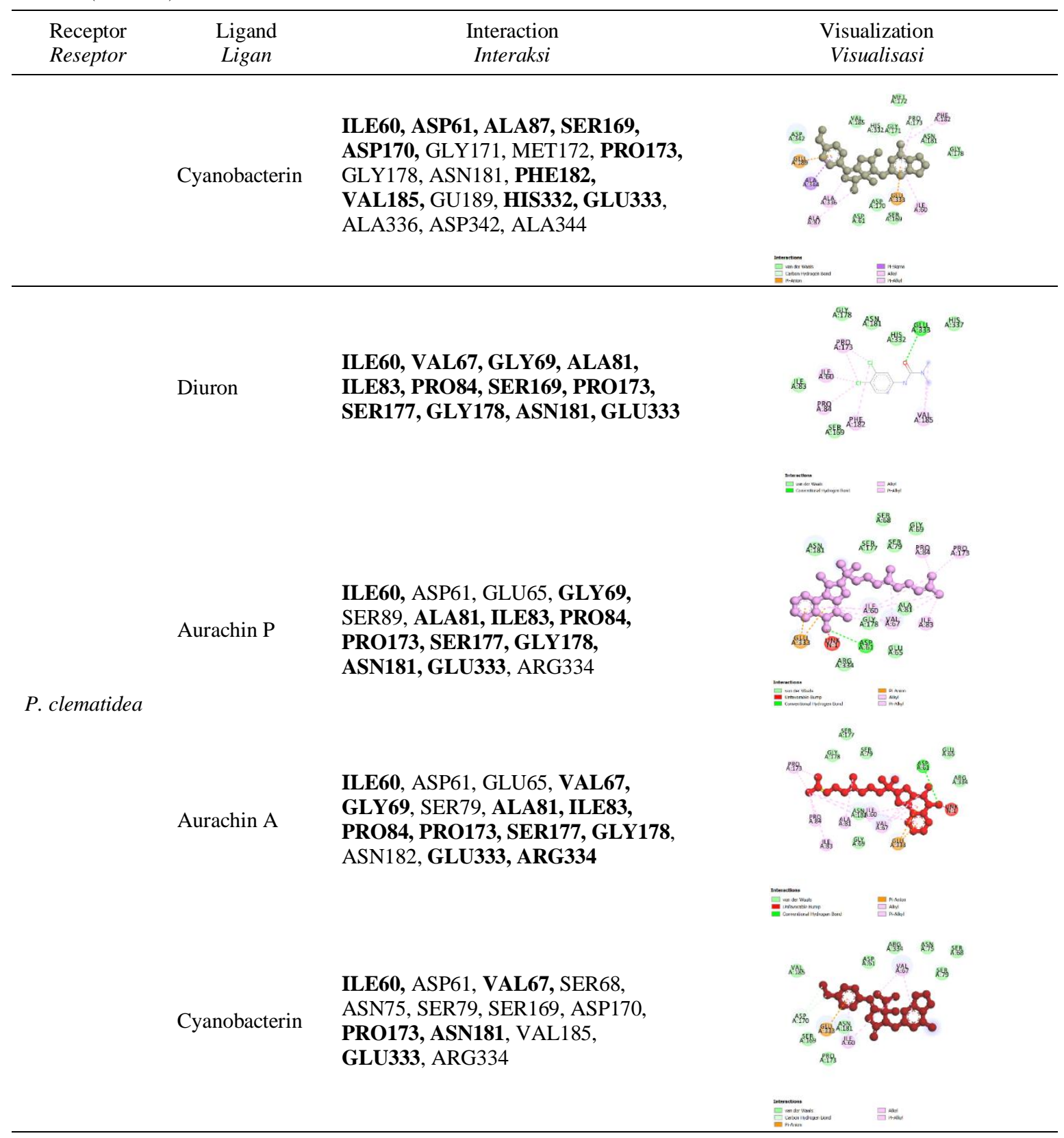

Biological activity of Aurachin P and Aurachin A was predicted to be related to the terms as an inhibitor in plastoquinol-plastocyanin reductase. This enzyme playing a role in the linear electron transfer chain that contributes to oxygenic photosynthesis in the chloroplast. Linear electron chain is responsible to oxidize water into molecular oxygen and reducing the NADP+ to NADPH. This condition makes the environment of transmembrane proton gradient which will be converted by ATP synthase into chemical energy (ATP). The plastoquinone enzyme catalyzes the electrotransfer between Photosystem II and I, which is the photosynthetic reaction centers of oxygenic photosynthesis (Gao et al., 2018). When this process was inhibited by Aurachin $\mathrm{P}$ and
Aurachin A, the photosynthesis process will not happen.

Cyanobacterin was predicted to have 1Acylglycerol-3-phosphate O-acyltransferase inhibitor activity. This enzyme playing roles in phosphatic acid biosynthesis. It may regulate neutral lipid accumulation and participate in lipid turnover regulation. The phospholipid is well known to play crucial roles in the development and signal transduction. It also regulates the homeostasis in growth and development stages under stress conditions. Phosphatic acid was proven to act as a key for thylakoid lipid biosynthesis in the chloroplast (Yao \& Xue, 2018). If this process were inhibited by Cyanobacterin, the growth of weeds will be terminated. 
Table 5. Biological activity prediction of Aurachin P, Aurachin A, and Cyanobacterin using the PASS server. Pa: Probability of activity

Tabel 5. Prediksi aktivitas biologis dari Aurachin P, Aurachin A, dan Cyanobacterin menggunakan PASS Server. Pa: prediksi aktivitas

\begin{tabular}{|c|c|c|c|c|c|}
\hline \multicolumn{2}{|c|}{ Aurachin A } & \multicolumn{2}{|c|}{ Aurachin P } & \multicolumn{2}{|c|}{ Cyanobacterin } \\
\hline Pa score & Activity & Pa score & Activity & Pa score & Activity \\
\hline Skor $\mathrm{Pa}$ & Aktivitas & Skor $\mathrm{Pa}$ & Aktivitas & Skor Pa & Aktivitas \\
\hline 0.752 & $\begin{array}{l}\text { Lipid peroxidase } \\
\text { inhibitor }\end{array}$ & 0.750 & $\begin{array}{l}\text { Prenyl-diphosphatase } \\
\text { inhibitor }\end{array}$ & 0.800 & $\begin{array}{l}\text { Membrane integrity } \\
\text { agonist }\end{array}$ \\
\hline 0.748 & $\begin{array}{l}\text { Prenyl-diphosphatase } \\
\text { inhibitor }\end{array}$ & 0.738 & $\begin{array}{l}\text { Undecaprenyl-phosphate } \\
\text { mannosyltransferase } \\
\text { inhibitor }\end{array}$ & 0.800 & $\begin{array}{l}\text { Aspulvinone } \\
\text { dimethylallyltransferase } \\
\text { inhibitor }\end{array}$ \\
\hline 0.734 & $\begin{array}{l}\text { Undecaprenyl- } \\
\text { phosphate } \\
\text { mannosyltransferase } \\
\text { inhibitor }\end{array}$ & 0.707 & $\begin{array}{l}\text { Plastoquinol-plastocyanin } \\
\text { reductase inhibitor }\end{array}$ & 0.800 & Carminative \\
\hline 0.721 & $\begin{array}{l}\text { Plastoquinol- } \\
\text { plastocyanin reductase } \\
\text { inhibitor }\end{array}$ & 0.726 & Antineoplastic & 0.700 & CYP2H substrate \\
\hline 0.741 & $\begin{array}{l}\text { Ubiquinol-cytochrome- } \\
\text { c reductase inhibitor }\end{array}$ & 0.723 & $\begin{array}{l}\text { Ubiquinol-cytochrome-c } \\
\text { reductase inhibitor }\end{array}$ & 0.600 & $\begin{array}{l}\text { 1-Acylglycerol-3- } \\
\text { phosphate O- } \\
\text { acyltransferase inhibitor }\end{array}$ \\
\hline
\end{tabular}

\section{Conclusion}

This study provided insight into the bioherbicide candidate compounds which has shown potentially better affinity than synthetic herbicide diuron. It is indicated that the Aurachin $\mathrm{P}$, Aurachin A, and Cyanobacterin were the best blocker candidate compounds for Photosystem II D1 protein to inhibit the growth of selected sugarcane weeds. However, efficacy tests are required to confirm the potential effectivity of the compounds found in this research.

\section{References}

Dallakyan S \& AJ Olson (2015). Small-molecule library screening by docking with PyRx. Methods Mol Biol 1263, 243-50. doi: 10.1007/978-1-4939-2269-7_19.

Dayan FE \& SO Duke (2014). Natural compounds as next-generation herbicides. Plant Physiol 166(3), 1090-105. doi: 10.1104/pp.114.239061. Epub 2014 Apr 30.

de Sousa ACC, Combrinck JM, Maepa K, \& Timothy JE (2020). Virtual screening as a tool to discover new $\beta$-haematin inhibitors with activity against malaria parasites. Sci Rep 10 , 3374. doi: 10.1038/s41598-020-60221-0.

Délye C, M Jasieniuk \& LC Valerie (2013). Deciphering the evolution of herbicide resistance in weeds. Trends Genet 29, 649-658. doi: 10.1016/j.tig.2013.06.001.

Eyal E, S Gerzon, V Potapov, M Edelman \& V Sobolev (2005). The limit of accuracy of protein modeling: influence of crystal packing on protein structure. J Mol Biol. 351(2), 43142.

Filimonov DA, DS Druzhilovskiy, AA Lagunin, TA Gloriozova, AV Rudik, AV Dmitriev, PV Pogodin \& VV Poroikov (2018). Computeraided prediction of biological activity spectra for chemical compounds: opportunities and limitations. Biomed Chem: Res and Methods l(1), 1-21. doi: 10.18097/bmcrm00004.

Gao J, H Wang, Q Yuan, \& Y Feng (2018). Structure and Function of the Photosystem Supercomplexes. Front plant sci 9, 357. https://doi.org/10.3389/fpls.2018.00357

Giacomazzi S \& N Cochet (2004). Environmental impact of diuron transformation: a review. Chemosphere 56(11), 1021-32.

Gianessi LP (2005). Economic and herbicide use impacts of glyphosate-resistant crops. Pest Manag Sci 61(3), 241-245. doi: 10.1002/ps.1013.

Hall T (2011). BioEdit: An important software for molecular biology. GERF Bulletin of Biosciences 2(1), 60-61

Huovinen M, J Loikkanen, J Naarala \& K Vähäkangas (2015). Toxicity of diuron in human cancer cells. Toxicol In Vitro 29(7), 1577-86. doi: 10.1016/j.tiv.2015.06.013. Epub 2015 Jun 15.

Kufareva I \& R Abagyan (2012). Methods of protein structure comparison. Methods $\mathrm{Mol}$ Biol. 857, 231-257. doi:10.1007/978-1-61779588-6_10. 
Kulkarni SA, Nagarajan SK, Ramesh V, Palaniyandi V, Selvam SP, \& Madhavan T (2020). Computational evaluation of major components from plant essential oils as potent inhibitors of SARS-CoV-2 spike protein. $J$ Mol Struct 1221, 128823. doi: 10.1016/j.molstruc.2020.128823.

Meng XY, HX Zhang, M Mezei \& M Cui (2011). Molecular docking: a powerful approach for structure-based drug discovery. Curr computaid drug 7(2), 146-157. https://doi.org/10.2174/157340911795677602

Morales MAM, BCV Camargo \& MM Hoshina (2013). Toxicity of Herbicides: Impact on Aquatic and Soil Biota and Human Health. Herbicides - Current Research and Case Studies in Use. USA, IntechOpen, DOI: 10.5772/55851.

Nusrat, Amrish Agrawal, N Kumar \& J Kumar (2018); Bio-Herbicides for Sustainable and Eco-Friendly Weed Control: A Review. Int J of Adv Res 6(12), 550-561.

Peng SY (2012). The biology and control of weeds in sugarcane. USA, Elsevier.

Pinzi L \& G Rastelli (2019). Molecular Docking: Shifting Paradigms in Drug Discovery. Int $J$ Mol Sci 20(18), 4331. https://doi.org/10.3390/ijms20184331

Radhakrishnan R, AA Alqarawi \& EFA Allah (2018). Bioherbicides: Current knowledge on weed control mechanism. Ecotoxicol Environ Saf 158, 131-138 doi: 10.1016/j.ecoenv. 2018.04.018

Salmaso V \& S Moro (2018). Bridging Molecular Docking to Molecular Dynamics in Exploring Ligand-Protein Recognition Process: An Overview. Front pharmacol 9, 923. doi:10.3389/fphar.2018.00923

Singh J \& Kumar R (2013). Management of weeds for sustainable sugarcane production in subtropical India. Indian J Sugarcane Technol., 28: 95-9.

Singh WD, RP Singh, RP Malik \& R Mehta (2011). Effect of planting density and weed management options on weed dry weight and cane yield of spaced transplanted sugarcane (Saccharum officinarum L.) after wheat harvest in sub-tropical India. Indian J Weed Sci. 43, 97100.

Sistem Informasi Pestisida (2020). http:// pestisida.id/simpes_app/. Accessed on August 7th, 2020. Direktorat Pupuk dan Pestisida Direktorat Jenderal Prasarana \& Sarana Pertanian, Kementrian Pertanian

Teixeira PF \& E Glaser (2013). Processing peptidases in mitochondria and chloroplasts. Biochimica et Biophysica Acta (BBA) Molecular Cell Research. 1833(2), 360-370

Velki M, C Lackmann, A Barranco, AE Artabe, S Rainieri, H Hollert \& TB Seiler (2019). Pesticides diazinon and diuron increase glutathione levels and affect multixenobiotic resistance activity and biomarker responses in zebrafish (Danio rerio) embryos and larvae. Environ Sci Eur 31, 4. https://doi.org/10.1186/s12302-019-0186-0

Venkateshan M, Muthu M, Suresh J, Ranjith \& Kumar R (2020). Azafluorene derivatives as inhibitors of SARS CoV-2 RdRp: Synthesis, physicochemical, quantum chemical, modeling and molecular docking analysis. J Mol Struct 1220, 128741. doi: 10.1016/j.molstruc. 2020.128741 .

Wakabayashi K \& P Böger (2002). Target sites for herbicides: entering the 21st century. Pest Manag. Sci. 58(11), 49-1154. doi: 10.1002/ps.560.

Wessels JSC \& RVD Veen (1956). The action of some derivatives of phenylurethan and of 3phenyl-1,1-dimethylurea on the Hill reaction. BBA-Gen Subjects 19, 548-549.

Yang J \& Y Zhang (2015). I-TASSER server: new development for protein structure and function predictions. Nucleic Acids Res 43, W174W181. doi: 10.1093/nar/gkv342.

Yao HY \& HW Xue (2018). Phosphatidic acid plays key roles regulating plant development and stress responses FA. J. Integr. Plant Biol. 60(9), 851-863. doi: 10.1111/jipb.12655. 